\title{
Usos intempestivos del patrimonio histórico y cultural de Occidente en la poesía de Aldo Oliva
}

Bruno Crisorio

Universidad Nacional de La Plata (UNLP, Argentina); CONICET.

«En la naturaleza las especies permanecen relativamente estables; los bastardos, en la naturaleza, se extinguen o son estériles desde el primer momento. En la vida histórica, en todo vemos la nota de lo bastardo, como si esto fuese un factor esencial para hacer fecundos otros procesos históricos.» (Jacob Burckhardt, Reflexiones sobre la historia universal)

«Yo... me siento un hijo ilegítimo de esta cultura y de este sistema. Tal vez por eso también me sumí en el ámbito marginal de la libertad iracunda.» (Aldo Oliva)

\section{Resumen}

Entre los papeles que dejó Aldo Oliva al morir se encuentra una especie de breve autobiografía, irónica, que terminó sirviendo de contratapa para su Poesía completa. Allí dice: «A los quince años me tropecé con la cultura: no la recuerdo». En un poeta como Oliva, cuya erudi-

\section{Palabras clave:}

Aldo Oliva, poesía, cultura, tradición, historia 
ción y paciente trabajo sobre la tradición occidental salta a la vista al primer poema que leamos, esta frase llama la atención. Pero, de hecho, el paradójico cruce entre tradición y novedad, entre cultura y olvido, recorre la obra del autor, produciendo una poética a un tiempo clásica y rupturista. A partir del análisis de algunos poemas de su último libro, Ese General Belgrano y otros poemas (2000), y de algunas reflexiones nietzscheanas sobre el peso de la historia para la vida, abordaremos este doble posicionamiento que configura, creemos, la singularidad de Oliva, e intentaremos rastrear las filiaciones que crean este campo tensionado. El «olvido" de Oliva, concluiremos entonces puede leerse en este sentido: como irreverencia frente al pasado, como lectura sesgada que horada su aparente completud para permitir la creación. La poesía (el arte) vuelve a poner en movimiento una tradición que parecía congelada, petrificada: como propone uno de los poemas analizados, que podría considerarse un arte poética, la poesía transforma emblemas en problemas, en "la aventura seminal del fruto».

\section{Abstract}

\section{Untimely Uses of Western Historical and Cultural Heritage in the Poetry of Aldo Oliva}

Among the papers Aldo Oliva left when he died, there is a kind of ironic autobiography that ended up in the back cover of his book Poesia Completa. There he says: "At the age of fifteen I ran into culture; I don't remember it». Such a statement sounds peculiar coming from a poet like Oliva, whose erudition and patient work over the western tradition is immediately evident. However, this paradoxical intersection between tradition and novelty, between culture and oblivion is to be found across the author's whole oeuvre; he produces a poetics that is at the same time classical and rupturist. Starting

\section{Keywords:}

Aldo Oliva, poetry, culture, tradition, history 
from the analysis of some poems from his last book, Ese General Belgrano y otros poemas (2000), and some Nietzschean reflections on the weight of history for life, we will approach this double positioning that conforms the singularity of Oliva, and we will try to trace the filiations that create this stressed realm. The "oblivion» of Oliva, we will conclude, can be read in this sense: as irreverence to the past, as a biased reading that pierces its apparent completeness to allow creation. Poetry (art) once again sets in motion a tradition that seemed frozen, petrified: as proposed by one of the poems analysed, which could be considered an ars poetica, poetry transforms emblems into problems, into «the seminal adventure of the fruit».

\section{Resumo}

\section{Usos intempestivos do patrimônio histórico e cultural do Ocidente na poesia de Aldo Oliva}

Entre os papéis que deixou Aldo Oliva ao morrer, encontra-se uma espécie de breve autobiografia, irônica, que acabou servindo de contracapa para sua Poesia completa. Aí diz: "Aos quinze anos me topei com a cultura: não a lembro». De um poeta como Oliva, cuja erudição e trabalho paciente sobre a tradição ocidental se faz visível no primeiro poema que lermos, esta frase chama a atenção. Mas, de fato, o paradoxal cruzamento entre tradição e novidade, entre cultura e esquecimento, percorre a obra do autor, produzindo uma poética ao mesmo tempo clássica e de ruptura. Partindo da análise de alguns poemas de seu último livro, Ese General Belgrano y otros poemas (2000), e algumas reflexóes de Nietzsche sobre o peso da história para a vida, abordaremos esse duplo posicionamento que configura, acreditamos, a singularidade de Oliva, e tentaremos rastejar as filiações que gera esse campo em tensão. $\mathrm{O}$ «esquecimento» de Oliva, concluiremos entáo, pode ser lido neste sentido: como irreverência perante o passado,
Palavras-chave:

Aldo Oliva, poesia, cultura, tradição, história 
como uma leitura tendenciosa que penetra sua aparente perfeição para permitir a criação. A poesia (arte) pôe em movimento uma tradição que parecia congelada, petrificada: como sugere um dos poemas analisados, que poderia ser considerado uma arte poética, a poesia transforma emblemas em problemas, na «aventura seminal do fruto».

\section{Introducción}

La figura de Aldo Oliva (1927-2000) ha quedado durante mucho tiempo asociada a la bohemia rosarina, primero, y luego a su lugar excéntrico en la Academia, como díscolo profesor de Literatura Argentina II y Literatura Europea II en la Facultad de Humanidades y Artes de la UNR. Ambos momentos (la bohemia y militancia de los ańos 50 y 60, y la docencia en la reapertura democrática), atravesados por el bar como espacio simbólico de discusión política, de precaria comunidad poética, y de ingesta alcohólica, fueron configurando un mito en torno a su persona que no se condecía con el reconocimiento de su obra poética, en buena medida porque el propio Oliva, con su desinterés por publicar, su «molicie» como él mismo la llama, dificultó el acceso a sus textos. Recién después de su muerte, gracias al trabajo de varios alumnos que recuperaron su legado poético, la obra de Oliva se empezó a difundir por fuera del selecto círculo de «iniciados», en una ola que sigue en expansión.
La primera edición de la Poesía completa es de 2003; su reedición en 2016, entre otras modificaciones (algunas importantes, como la acertada inclusión de una serie de traducciones de poetas clásicos y modernos realizadas por Oliva), incluye un cambio en la contratapa que parece intrascendente, pero nos dio el punto de partida, la pregunta inicial para pensar este trabajo. Si en la primera versión la contratapa presenta una semblanza de Oliva, realizada probablemente por Roberto García (editor y prologuista del libro), aquí se encuentra un breve fragmento claramente autobiográfico, en el que el propio autor resume su vida en clave paródica. Según nos aclara Roberto García en el prólogo, la nota (que ya había aparecido en una edición local y de poca tirada de sus poemas inéditos y póstumos) fue encontrada «entre sus papeles, entreverada con poemas, textos de sus clases o charlas» (2016:12). Allí, una frase del poeta llama la atención inmediatamente: «A los quince años me 
tropecé con la cultura: no la recuerdo». Esta afirmación quizá no sorprendería si proviniese de algún poeta de los '9o: después de todo esta generación (con la generalización que conlleva, siempre, hablar de "generación») se caracterizó por hacer un culto de la incultura y afirmar tajantemente un presente sin raíces ni tradiciones, disimulando, a veces trabajosamente, sus conocimientos nada desdeńables, y que han aflorado con posterioridad. Tampoco sería extraño si Oliva reivindicara una herencia vanguardista, cuyos intentos por romper definitivamente con la tradición son conocidos (recordemos al pasar la frase, tomada de Descartes, que encabezaba una de las primeras publicaciones dadaístas: «No quiero ni siquiera saber si antes de mí hubo otro hombre»). Pero en el caso de Oliva la cosa se complica.

Primero porque se distancia decididamente de ambas posiciones: desdeña las vanguardias, más allá de la recuperación de algunos poetas y del reconocimiento de aportes puntuales; y respecto de la poesía de los '9o, que no es su generación pero sí es la década en la que publica sus libros, todo su proyecto literario parece contraponerse punto por punto a la hegemonía poética del momento. ${ }^{1}$ Segundo, y fundamentalmente, porque su propio trabajo poético parece desmentir rotundamente la afirmación. Oliva inaugura su primer libro con una traducción parcial de la Farsalia de Lucano, y fue sorprendido por la muerte trabajando poéticamente sobre De rerum natura, fundamentalmente a partir de la concepción lucreciana de los simulacra. Entre ambos extremos, el acercamiento al acerbo cultural de occidente, desde la Antigüedad Clásica a la Modernidad y el Modernismo, es permanente, como lo demuestra casi cualquier poema del autor elegido al azar, o las traducciones realizadas de Catulo, Filóstrato de Atenas, Nerval o Baudelaire. ¿Qué pensar, entonces? ¿Qué significa este olvido cultural en alguien cuya vasta erudición deja muchas veces afuera al lector, obligado a seguirlo por los meandros de la tradición occidental, desde Homero hasta César Vallejo, pasando por Dante, Shakespeare, Baudelaire y Rubén Darío? De hecho, su «tropiezo con la cultura» es su encuentro con el poeta nicaragüense: a los catorce ańos lee por primera vez a Darío, y su

1 En una entrevista de 1988, Oliva rescata a Francisco Madariaga de "la fastidiosa avalancha de los surrealistas ortodoxos, tanto argentinos como franceses" (2016 [1988]:5), mientras que diez años después se reconocerá "antidadaísta” (2016 [1998]:24). Sobre su renuencia a publicar, que lo lleva a postergar su primer libro hasta que tiene casi sesenta años, y su posicionamiento voluntariamente marginal en el campo literario de los ' 90 , cuando finalmente aparecen sus libros, véase Aguirre (2006), Barrella (2006) y Crisorio (2017a). 
fascinación corre pareja con su parálisis: «Yo decía: como este puedo escribir, pero cuando apareció Darío, me dije: "Cómo voy a poder escribir igual que él”" (2016 [1998]:24). Su modo de superar ese momento de inhibición fue copiar a mano la antología de Darío que tenía: «Como acto, ahí empecé a escribir» (24). ${ }^{2}$

La historia es contada por Oliva en varias entrevistas, incluida esta publicada dos años antes de su muerte, y García la transforma en biografema al decir que «En el acto de repetir la escritura del otro comienza a fundarse la posibilidad de una nueva escritura (...). Transcribir, reversionar, traducir, citar, repetir seguirán siendo los átomos que en el futuro, en su corriente estocástica, inauguren la imperceptible deriva de la creación poética» (2016:I2-13). ¿Qué quiere decir, entonces: «A los quince años me tropecé con la cultura: no la recuerdo»? ¿Cómo conjugar esta anécdota, que remite sus comienzos como escritor al encuentro con la cultura, con el reconocimiento final de su olvido de esta misma cultura?

\section{La historia, la cultura}

A esta altura podría pensarse que la frase, en sí, no merece la atención que le estamos dando. Después de todo el fragmento es una autobiografía irónica, burlona, y probablemente Oliva no pensara en publicarla. Hay sin embargo dos cuestiones que nos llevan a mantener la mirada fija en la frase, y a preguntarnos por su sentido. La primera es que el autor ya había manifestado, en una entrevista de I988, su relación conflictiva y problemática con «la cultura». La segunda es que este olvido cultural nos permite pensar ciertas operaciones de escritura que quizá de otro modo permanecerían en las sombras.

Hacia el final de la entrevista que le realizan Martín Prieto y García Helder para Diario de poesía, y a propósito del «extraño matrimonio» entre Darío y el surrealismo que se encuentra en su obra, Oliva afirma que «los mejores hijos a veces son bastardos, son hijos de acoplamientos pasajeros, no tienen la presión de los padres» (2016 [1988]:6). Frente a los

2 Una segunda parte de la anécdota, que García no recupera en su prólogo pero aparece en varias entrevistas, es también interesante y empieza a orientar la propuesta del presente trabajo. La misma amiga de la familia que le regala a Oliva los papeles en los que "copiará" a Darío, le regala en una oportunidad La cuádruple raíz del principio de razón suficiente, de Schopenhauer, "que tenía largas parrafadas en latín, largas parrafadas en griego. Yo leía todo y, obviamente, no entendía nada" (2016 [1988]:2). En el origen, por lo tanto, no está solo la fascinación y la copia, sino también la incomprensión, el vacío o hueco no llenado por el sentido que va a abrir las puertas a la creación personal. 
hijos legítimos — «los que flotan sobre el mar», «los que quieren esta cultura»-, él se siente un bastardo, un hijo ilegítimo, y eso, sospecha, es lo que le permite un margen de libertad iracunda. Aquí se superponen, implícitamente, dos concepciones de la cultura. Cultura como zeitgeist, como época, como modo de ser de un pueblo o un grupo social en un momento determinado (la RAE la entiende como el «conjunto de modos de vida y costumbres, conocimientos y grado de desarrollo artístico, científico, industrial, en una época, grupo social, etc.»); cultura como patrimonio histórico, artístico, político, religioso, valorado y venerado. Claro está, la cultura como presente, como corte sincrónico (lo que Oliva llama flotar sobre el mar), se intersecta con la cultura como historia y tradición (las genealogías y filiaciones), pero lo interesante es cómo el autor hará jugar en su obra un aspecto contra el otro, en busca de la novedad, el desvío y la reinvención. Prieto y Helder lo captan bien al vincular, extrañados, surrealismo y modernismo en la obra de Oliva; pero se podría ser más audaces, y rastrear las imposibles comunicaciones entre Lucano, Catulo u Homero, y Baudelaire, Nerval o César Vallejo.

De hecho, la manera en que Oliva se relaciona con la cultura (entendida fundamentalmente en el sentido de tradición) se explica más sutilmente en la entrevista que en el fragmento póstumo. Porque un hijo ilegítimo no deja de ser un hijo, no corta todo vínculo con el pasado que lo conforma (esa ilusión vanguardista), pero decide él las formas y los alcances de ese vínculo. Al no tener la presión de los padres, se encuentra como el escritor argentino según Borges: habilitado para retomar cualquier tradición, sin la obligación de seguir ninguna. $\mathrm{Y}$ sobre todo, con libertad para transformar, recrear o mezclar esas tradiciones de las que se sirve. En este sentido, la cultura que Oliva dice haber olvidado hacia el final de su vida no es tanto el patrimonio histórico y artístico legado por Occidente como la tradición totalizadora que, en el momento de su transmisión, congela los monumentos que transmite, les otorga un sentido unívoco y definitivo y clausura todo intento de acercamiento vivo y deseante con el pasado. García habla en su prólogo de «generar una voz audible frente al imperio de un lenguaje ya dicho e inamovible» (2016:26), y de "reescribir el canon cerrado de lo real» (46). Pero no se trata sólo de eso: también hay que liberar los textos canónicos (La Farsalia, las Metamorfosis de Ovidio o la Jerusalén Liberada de Tasso) del lugar inequívoco que ocupan en la historia de la literatura, 
para abrirlos a nuevas lecturas, nuevas interpretaciones, nuevas escrituras. Para ponerlos nuevamente en movimiento. ${ }^{3}$

Para el Nietzsche de las Consideraciones intempestivas, el exceso de historia asfixia la vida. Un individuo o un pueblo volcado exclusivamente hacia el pasado, y a un respeto reverencial por ese pasado, se marchita por no dejar espacio alguno para la novedad, para el presente en pugna: como señala Foucault, a un historicismo excesivamente preocupado por el rigor y la objetividad, "las Intempestivas objetaban que corría el riesgo de evitar toda creación en nombre de la ley de fidelidad» (Foucault 1992:27). «Toda acción requiere olvido", afirma Nietzsche (2002:2I). Sin embargo, pese a que a lo largo del texto el autor enfatiza la importancia del olvido (como reacción al esclerótico historicismo imperante en su época), reconoce que «lo histórico y lo ahistórico son igualmente necesarios para la salud de los individuos, de los pueblos y de las culturas» (23). Oliva erigirá su propia obra entre la historia y el olvido, entre la acumulación y la destrucción que «hace sitio y despeja», en palabras de Walter Benjamin, y que Oliva llamará «fisura aperturista». ${ }^{4}$ Esta fisura es provocada por la visión, que el autor distingue de la simple mirada por estar «insuflada por el deseo» (Oliva, 2000:13). La urgencia presente hiende el pasado, lo transfigura e incluso incide en las propias formas poéticas: Oliva trabaja con metros propios del castellano, fundamentalmente el heptasílabo y el endecasílabo (y en un segundo lugar el eneasílabo y el alejandrino), pero los descompone, los astilla, los fragmenta, retiene su impulso. Los fractura, y así ritmos tradicionales circulan por sus poemas como ríos profundos que sin embargo responden a formas nuevas.

La visión, al estar ligada indisolublemente con los deseos presentes e indomeñables (en este caso, la pulsión poética), se dirige al pasado pero para traicionarlo, perturbarlo o desgarrarlo, ${ }^{5}$ y hacer así lugar para «esa oculta furia/ asediando lo

4 Octavio Paz entiende que esta relación paradójica con la historia es propia de la poesía: "Un poema es un objeto hecho del lenguaje, los ritmos, las creencias y las obsesiones de este o aquel poeta y de esta o aquella sociedad. Es el producto de una historia y de una sociedad, pero su manera de ser histórico es contradictoria. El poema es una máquina que produce, incluso sin que el poeta se lo proponga, antihistoria. La operación poética consiste en una inversión y conversión del fluir temporal; el poema no detiene el tiempo: lo contradice y lo transfigura" (2005:9).

5 En el poema "Titirimundi" (del libro De fascinatione, de 1997), uno de los textos en los que Oliva parte de una figura histórica (el general de Bohemia "Zizka el ciego"), se habla de la "visión desgarrada" (2016: 128); mientras que en "D.N.I." (publicado en Ese General Belgrano y otros poemas, 2000) será "esa visión perturbada/ por la vorágine de la altura" (2016:215). La visión es desgarrada, pero 
desconocido/ llamado presente», como hace decir Oliva a Manuel Belgrano momentos antes de morir (Oliva, 20I6: 289). Todo el extenso poema llamado "Ese General Belgrano», que da título al último libro publicado en vida de Oliva y del cual extrajimos la cita anterior, se ubica de hecho bajo el signo de la desobediencia: desobediencia de Belgrano frente al Triunvirato de Buenos Aires («Tal vez algunos, que se decían/ solidarios de la Revolución,/ marcaron mi ruta»; 287), pero también desobediencia de la poesía frente a los designios de la historia: «De ahí: reverdecer o asumir la muerte./ De ahí, la creación de un poema/ que lo escriba y lo diga./ De ahí la historia de un poema/ sin historia. De ahí la grandeza/ de los que abdicaron de la Grandeza» (287-288). Reverdecer o asumir la muerte: reverenciar pasivamente el pasado, anquilosarse en la repetición, o bien, siguiendo el «clamor errabundo del deseo" (99), atravesar la historia en busca de las "constelaciones de ausencia» en las que «esplende, ya, la explosión/ de lo que llaman imposible» (289).

\section{Los poemas}

El olvido de Oliva puede leerse así en este sentido: como irreverencia frente al pasado, como lectura sesgada que horade su aparente completud para permitir la creación. En varios de sus poemas, Oliva se pregunta por la posibilidad (y las condiciones) de la novedad, de la creación a partir de la nada: «Algo forja materia/ de fuerza sísmica/ en la escala, vertiginosa, de lo inexistente» (222). El poema se llama «El abrazo imposible de la Venus de Milo» y ancla inmediatamente en la tradición latinoamericana, en el Rubén Darío que plagió a los quince años. Pero Oliva, y es un intento constante en su obra, se apoya en la tradición para escapar de ella, consciente de la ingenuidad (cuando no mala fe) que implica la búsqueda poética del fulgor inmediato, inocente, no tamizado por la historia de la lengua y de esa cultura que pretende olvidar. «La historia designa únicamente el conjunto de condiciones, por muy recientes que éstas sean, de las que uno se desvía para devenir, es decir para crear algo nuevo (...) Sin la historia, el devenir permanecería indeterminado,

\footnotetext{
también desgarra, abre, y así leemos en "De cómo Odiseo fue Ulises y de sus avatares" (De fascinatione): "...otros/ urden, desde el recuerdo,/ una visión o un gesto/ que les abra el espacio/ para ser vistos/ por un ojo ya desvanecido" (120). En cambio, la "prolija visión" es explícitamente negada en "Epigráfica del Ehret", escrito en 1977 (2016:102); y en "Aldebarán (tango)", publicado en De fascinatione, el niño del poema se encuentra "de espaldas, en leve ensueño tendido;/ la mirada, libre de la visión, vaga en la fraternidad de las nubes" (140). La visión, a diferencia de la mirada, es tempestuosa y disruptiva, es terreno de conflictos entre destino y deseo.
} 
incondicionado, pero el devenir no es histórico» (Deleuze y Guattari, 1995:97); el desvío, el clinamen epicúreo, es una figura que describe bien el trabajo de Oliva con la tradición. ${ }^{6}$ El desvío vuelve a poner la historia en movimiento, la despierta del pesado sueño en que dormía en los anaqueles de historiadores y académicos para restituirla a la vida y al presente, en un gesto disruptivo e irreverente (sísmico según la cita anterior) porque obedece a energías nuevas en pugna por tomar forma.

Hasta ahora hemos retomado parcialmente poemas de De fascinatione y de Ese General Belgrano; ahora nos adentraremos, más en profundidad, en un poema de este último libro, «Emblema-Problema», ${ }^{7}$ ya que tematiza de modo explícito las relaciones entre historia, cultura, arte y poesía. El libro está dividido en tres secciones: «Imágenes renuentes», «Avizoramientos en el espejo retrovisor» y "Ese General Belgrano». La última parte es un poema extenso sobre la figura de Belgrano, dividido en cuadros y movimientos, que según Roberto García el autor prometió durante mucho tiempo pero no parecía capaz de terminar (2002:7); la primera, un conjunto de poemas cortos, «fueron el paralelo revulsionado de la inacción de la escritura del Belgrano, o dicho en su reverso: la acción escrituraria compulsiva de su fracaso momentáneo frente al poema mayor mientras este permanecía inconcluso" (8). ${ }^{8}$ De acuerdo con un procedimiento ya explorado por Oliva, ${ }^{9}$ la apropiación trabajosa de la historia

6 cf. el prólogo de Roberto García (2016:36-37) y el poema de Oliva "Elegía» (2016:134).

7 Como centraremos el análisis en este poema en particular, a continuación lo citamos completo: "Jamás existió el tiempo.// Una catarata (pensemos/ que infinita) de seres caducos/ se precipitó en hondas rocas,/ en las zanjadas quebraduras de tierra de variado declive/ como caudales de agua primigenia;/ y percibieron ya, en última mirada,/ el sonrosado misterio/ de la sangre/ en la linfa clara.// Esa develación (en realidad,/ lo que llamamos muerte)/ iluminó los ojos/ de los que aún no habían/ caído.// Olas de lucubraciones,/ que llamamos cultura/ (cruentamente inhibidas,/ falazmente exhibidas,/ preñadas de terror/ o de vanidades compartidas),/ deslumbraron articulaciones/ de secuencias Ilamadas Historia.// Se consolidó el aura/ del conocimiento.// Pero el aura es una obsesión emblemática;/ mas el saber es el saber del movimiento/ de las arboladuras hurgando,/ en la irradiante soflama de la Rosa/ de los Vientos, un problemático/ derrotero de sentido.// La Flor,/ en su esplendor, no es un emblema,/ es un problema: es la aventura seminal/ del fruton (Oliva 2016:211-212).

8 El título de la parte intermedia, Que no abordaremos aquí, es una metáfora perfecta de la relación de Oliva con el pasado: la mirada hacia adelante recorta un fragmento de la historia en el espejo retrovisor, pero ese fragmento se modifica a medida que el observador se mueve.

9 El primer poema de su primer libro publicado, César en Dyrrachium (1986), consta de dos partes: en palabras del propio Oliva, la primera es "una versión, fragmentaria y relativamente libre, del Libro 
por parte de la poesía (que no implica solamente un saber historiográfico sino el contacto directo con documentos y fuentes de la época), su lenta intromisión en «la certeza ilustre del discurso histórico» (Oliva, 20I6:237) para hacerlo estallar desde dentro, va arrojando una serie de restos irreductibles que se formalizan y transforman en cuerpos poéticos independientes. En este sentido lo que propone García es acertado, pero debe entenderse que las «imágenes renuentes» no son exclusivamente el resultado negativo de su intento principal. Son también las respuestas poéticas (por lo tanto no unívocas) a una serie de preguntas que va suscitando el cara a cara entre poesía e historia. Preguntas filosóficas, teóricas, incluso antropológicas.

«Emblema-poema» es el quinto poema de las «Imágenes renuentes», y comienza con una afirmación tajante y paradójica: «Jamás existió el tiempo». La afirmación agota el verso, y un espacio en blanco lo separa de lo que podríamos llamar la primera estrofa. Así, la evidenciación de la frase presidirá la lectura del poema, que quedará bajo su égida. Ahora bien, ¿qué puede querer decir que jamás haya existido el tiempo? La expresión no sólo contradice la experiencia (una forma pura a priori de la sensibilidad, según Kant) sino que su misma formulación es lisa y llanamente paradójica: el adverbio temporal sumado al verbo en pretérito niegan esa negación del tiempo (nada distinto hacía Borges en Otras inquisiciones, al proponer una «Nueva refutación del tiempo») y vuelven al verso altamente polisémico e indeterminado. Pero sí hay una concepción de la temporalidad que es abolida en el poema, una concepción lineal y homogénea que es reemplazada por la tensión dicotómica inmovilidad/ movimiento, emblema/problema, conocimiento/saber, historia/aventura. El poema anterior, «En el teatro», nos orienta sobre cómo entender esta forma del tiempo: «Siento que ya me sumergí/ en el espectáculo:/ que lo que será, ya fue/ en los carteles publicitarios; (...) No pretendo abolir,/ con lánguida comodidad, la explosión radical del futuro inmediato.// Pero ya estoy en el teatro» (2016:209). Si todos los poemas de las «Imágenes renuentes» dialogan implícitamente en torno a algunos ejes como el tiempo, el instante, la creación y la muerte, aquí se contraponen precisamente dos tiempos: el tiempo del teatro, de la repetición calculada de los gestos y las palabras, tiempo del espectáculo que asfixia la

VI de la Pharsalia", mientras que la segunda parte, llamada "Aliter", es un "intento de consumación, también poemática, de las resonancias antropológicas liberadas en el curso de la estructuración textual de la “Diégesis” y su denotación histórica” (2016:59). 
novedad para devolver lo ya sabido, lo conocido y tautológico; y el tiempo del acontecimiento, de «la explosión radical del futuro inmediato" sobre el cual el sujeto lírico, al menos en este poema, no deposita mucha confianza. ${ }^{10}$

En «Emblema-Problema» la cuestión se complejiza. Luego de la tajante afirmación inicial, el poema pareciera estructurarse en tres momentos, de acuerdo a una exposición argumentativa evidenciada en la articulación lógica, en las aclaraciones parentéticas, en la voluntad de acordar el significado de las palabras, y en el borramiento del sujeto en busca de una exposición más objetiva (este discurso está sin embargo transgre- dido por la profusión de imágenes, las afirmaciones contradictorias o paradójicas y las rupturas métrico-sintácticas). El primer momento está compuesto de dos estrofas irregulares, y remite a lo real crudo, intenta nombrar aquello para lo que no existe nombre porque es anterior al lenguaje: «Esa develación (en realidad/ lo que llamamos muerte)». ${ }^{\text {II }}$ Los versos iniciales nos invitan a concebir la vida como un flujo homogéneo y predeterminado: «Una catarata (pensemos/ que infinita) de seres caducos/ se precipitó en hondas rocas». La imagen está recorrida por una inercia particular: primero, está sometida a la ausencia del tiempo ya predicada; segundo, la pausa versal intro-

10 De acuerdo con Roberto García (2002), Ese General Belgrano... fue compuesto bajo un influjo saturnino y melancólico que se evidencia en la negrura y pesimismo de las composiciones. Si bien esta aclaración debe ser matizada y, sobre todo, complejizada (algo de lo que intentaremos en las páginas siguientes), es cierto que muchos de los poemas supuran bilis negra, y traslucen la desesperanza del sujeto respecto al futuro (político fundamentalmente, pero también personal) y la incapacidad para cambiarlo. Este costado melancólico recorre sin embargo toda la obra de Oliva, unido además a la reflexión textual e incluso teatral que implica por un lado la noción de destino escrito, y por otro el cerrarse del sujeto sobre sí mismo, imposibilitado para operar en la vida real. La serie de la "Epigráfica del Ehret" (que, fechado en 1977, puede interpretarse como una suerte de duelo imposible por los ideales políticos y sociales de los '60 y '70) contiene numerosas referencias metatextuales y autorreferenciales, y convoca como compañero intertextual a la figura de Hamlet, el melancólico por excelencia (2016:99-104). Al respecto, ver Crisorio (2017b).

11 Incrédulo ante la posibilidad de soldar definitivamente "las palabras y las cosas", Oliva referirá recurrentemente al acto de nombrar, como si lo nombrado resistiera al nombre y no se disolviera en él; además del poema analizado, ver, en este mismo libro, el poema "Myrmekes": "Era algo parecido a la quietud,/ en lo que al surgir o al caer,/ después,/ Ilamamos muerten (2016:260). Un ejemplo precioso se encuentra en "Aliter", donde, hablando del mar, el sujeto lírico aclara: "(esa loca esmeralda/ que un sueño llamó Adriático/ y la Galia ulterior, "vagues de rêves")" (78). La única manera de nombrar la realidad es mediante la reinvención poética, la metáfora que devuelve la vida a lo que nombra: «loca esmeralda" está más cerca del mar que "Adriático". 
duce una reflexividad que retiene el verbo "pensemos» y lo vuelca retroactivamente sobre la catarata; finalmente, el segundo verso citado contrapone la infinitud de la catarata a la caducidad de los seres. Así, la tempestuosa cascada queda de algún modo neutralizada y llevada a un movimiento ciego y constante que encuentra su equilibrio final en la muerte.

Para enmascarar de signos a la muerte (según dice el primer poema de Ese General Belgrano..., "Travesía», solo algunas páginas más atrás) es que advienen la historia y la cultura, de lo que se hablará en el siguiente momento. Citemos la tercera estrofa: «Olas de lucubraciones,/ que llamamos cultura/ (cruentamente inhibidas, / falazmente exhibidas,/ preñadas de terror/ o de vanidades compartidas), deslumbraron articulaciones/ de secuencias llamadas Historia. Se consolidó el aura/ del conocimiento». La serie de instantes equivalentes que conformaban la catarata se articulan y secuencian en la Historia, que no es sino la forma que la cultura se da a sí misma, el modo en que un presente configura un pasado para legitimarse. El ritmo se acelera mediante la repentina regularidad de los versos (mayormente heptasílabos), otorgando unidad al paréntesis que explica qué ha de entenderse por cultura y cómo se estructuran estas «lucubraciones» (según la RAE, «lucubrar» es «elaborar una divagación complicada y con apariencia de profundidad», «imaginar sin mucho fundamento»): reprimiendo algunos aspectos, ostentando otros para que ingresen al espectáculo, si hemos de seguir la metáfora del poema anterior, reuniendo así el terror y la vanidad. ${ }^{12}$ Esas olas, infundadas, cruentas y falaces, consolidan finalmente el aura del conocimiento, la cultura se inviste con un carácter sacro, noble y definitivo: con el carácter de lo cierto e indudable.

El tercer momento, que tiene lugar en las dos últimas estrofas del poema, es el de la explosión lírica, el clinamen disruptivo que se va a rebelar tanto contra la inercia de lo meramente vivo como contra el peso asfixiante de la cultura (lo que en «Aliter» el poeta llamará «la mano de poder»): la creación. Según la exposición

12 Un poema posterior, llamado "Solapadas historia y arte", retomará esta convivencia entre horror y vanidad según una lógica que recuerda la relación benjaminiana entre cultura y barbarie: "Paloma de Picasso, figurones de Miró,/ lúbricos escamoteos de la lucha,/ emblemas de las líneas sometidas/ a la siniestra paz maquillada; incididas,/ perpetradas como vectores enmascarados/ que se afinan a la estratégica secesión/ de las conjeturas virtuales de una masacre" (2016:237). Las obras de arte son así entendidas como "emblemas" (palabra que nos reenvía al poema que estamos analizando, y sobre la que volveremos) de la "siniestra paz maquillada", de la masacre virtual y conjetural porque, al ser inhibida, no cuenta con datos ciertos y debe imaginarse. 
argumentativa del poema, la anteúltima estrofa desarrolla la contraposición entre el segundo y tercer momento, y la última concluye. Vamos por partes. La anteúltima estrofa (la cuarta del poema, si no contamos el verso inicial) distingue, a partir de dos adversativas ubicadas a comienzo de verso, entre el aura, «obsesión emblemática», y el «saber del movimiento» que es un "problemático/ derrotero de sentido». Una reconducción de este poema a la emblemática renacentista y posteriormente barroca, a aquellas «recopilaciones de dichos y proverbios acompañados de imágenes» (Ginzburg, I999:98) en relación dialéctica, creando una ilusión de correspondencias que «apelaba además a la relación armónica tradicional entre el macrocosmos y el microcosmos» (Egido, 1985:8-9), sería no solo posible sino necesaria. Nos daría más de una clave para comprender uno de los temas fundamentales de la obra de Oliva, como son las relaciones, relevos y tensiones entre palabra e imagen (poéticas, históricas, políticas). Sin embargo, un abordaje de este tipo nos alejaría demasiado del objetivo del presente trabajo. Baste por lo pronto decir que, en la economía semántica del poema, el emblema fija la imagen, la petrifica otorgándole un sentido unívoco y un lugar determinado en la cultura, mientras que el saber restituye un movimiento que no es ya el movimiento monocorde del comienzo, sino que es problemático, errático incluso. ${ }^{13}$

Esta estrofa pone en funcionamiento una metafórica marina: arboladuras, Rosa de los Vientos, derrotero. Esta serie de imágenes completa la idea: la alternativa a lo muerto y cristalizado no es el azar, ciego y alocado, sino un camino incierto que no deja de buscarse, y de trazarse a medida que se navega. Pero el encabalgamiento en "...Rosa/ de los Vientos...» habilita una segunda serie semántica que insiste en los demás poemas del libro y prepara la estrofa final. Nos referimos a la imaginería floral y vegetal como campo de lo feraz, como sinécdoque de la simiente que inaugura una nueva vida. $\mathrm{Al}$ igual que el primer verso del poema, esta última estrofa también tiene la forma de una afirmación tajante, concluyente: «La Flor,/ en su esplendor, no es un emblema,/ es un problema: es la aventura seminal/ del fruto». Este esplendor, fugaz pero cargado de un futuro incalculable,

13 En la entrevista realizada por Osvaldo Aguirre, Oliva explica esta concepción casi con los mismos términos que el poema: "En el tránsito de ella [viene hablando de lo que llama "visión"] a la producción del objeto poético puede alcanzarse un conocimiento, diría más bien un saber, para no cargarlo de acepción conceptual (...). Porque un concepto encapsula y cierra el sentido, detiene. Y el poema es una formalización y al mismo tiempo un continuo levantamiento de sentidos" (2016 [1994]:16). 
hiende el tiempo repetitivo o bien petrificado (el tiempo vacío y, en cierto sentido, inexistente del primer verso) y lo abre al acontecimiento. En ese sentido, la transformación de la Rosa en Flor no es casual. Otra de las «Imágenes renuentes» se llama «Juegos florales», y comienza diciendo «Si ha de salvarte, sólo será una flor». Luego de la enumeración de una serie de flores concretas a las que, a partir de la anáfora en «no», se niega la capacidad de salvación (las primeras son justamente «el lirio emblemático» y la «Rosa de los Vientos», pero luego siguen la alhucema, la margarita y el Jazmín del Cabo), se retoma el primer verso y se explica: «Sólo una Flor podrá salvarte,/ porque aún no es». Es la posibilidad misma la que brilla antes de concretarse, la Flor antes de ser lirio o alhucema. Es la potencia informe, «esa oculta furia/ asediando lo desconocido", que pugna por tomar forma y quizá lo logre en el poema.

\section{Conclusión}

Pero no hay que creer que el poema, propiamente hablando, sea equivalente al "problema» (si seguimos la terminología del propio Oliva), a aquello que escapa a la Historia y la cultura. Es más bien el conjunto "emblema-problema», el contrapunto dialéctico entre ambos extremos. El poema necesita del emblema, parte justamente de él: hablando de César en Dyrrachium, Oliva señala que «El punto de partida está siempre para mí en algún problema de tinte emblemático; un fragmento de la aprehensión del mundo me da el parti pris» (2016 [1993]:9). Entonces, el poeta se vuelca hacia la cultura en tanto "obsesión emblemática», hacia un fragmento del mundo que puede ser un episodio histórico (la revolución francesa en «Relojes», las revoluciones husitas en «Titirimundi» o la vida de Belgrano en «Ese General Belgrano»), un monumento artístico o literario (el «Perseo» de Cellini en "Benvenuto in Loggia», la Jerusalén liberada de Tasso en «La escritura de Severino»), incluso el cruce de los dos, ya que la historia rerum gestarum, el discurso histórico, es también un problema de escritura (tenemos allí la batalla de Dyrrachium narrada por Lucano y traducida por Oliva). Pero la visión lírica trasciende el fragmento, y sobre todo lo absuelve: lo libera de las garras en que la tradición lo tenía fijado y clasificado, y lo abre al continuo levantamiento de sentidos del que habla en la entrevista, que no es ya propiedad exclusiva del objeto sino que nace del encuentro, único e improbable, de este con un sujeto. El «olvido» del que habla Oliva jocosamente en su pequeña autobiografía, la bastardía de sus relaciones con la cultura de la que habla en otra entrevista, tienen para nosotros este sentido positivo, y no exclusivamente pasivo: el arrebato intempestivo a la tradición de aquellos «emblemas» con los que el sujeto entra en una relación inmediata y fulgurante, que ya no obedece a la lógica 
monocorde y acumulativa de la historia "VERRÀ LA MORTE E AVRÀ I TUOI OCCHI,/ sino que sigue el «clamor errabundo del Patria inexistente» (20I6:290). ¿Qué puedeseo» en busca del «esplendor,/ posible, de querer decir (más allá del intertexto de lo que no es» (en «Idilio», 20I6:224). anacrónico con el poema de Pavese), sino Al final del extenso poema sobre que la patria está siempre en proceso de Belgrano (el creador del «emblema» na- ser, siempre por venir, abierta al futuro cional, no lo olvidemos), el prócer dice: como una herida, como la muerte?

Referencias bibliográficas

- AGUIRRE, O. (2006). La tradición de los marginales. En Fondebrider, J. (Comp.). Tres décadas de poesía argentina 1976-2006 (pp. 45-56). Buenos Aires: Libros del Rojas.

- BARRELLA, S. (2006). Una política de autor. Diario de poesía, (73), 22.

• BURCKHARDT, J. (1980). Reflexiones sobre la historia universal. México: Fondo de Cultura Económica.

- CRISORIO, B. (2017a). Aldo Oliva: un fantasma en la poesía argentina. Estudios de teoría literaria. Revista digital: artes, letras y humanidades, 6(11), 203-216. Recuperado de: https:// fh.mdp.edu.ar/revistas/index.php/etl/article/view/1723/2151 -_-_ (2017b). Las cenizas del pasado. Una lectura de la "Epigráfica del Ehret" de Aldo Oliva. A contracorriente, 14(2), 95-114. Recuperado de: https://acontracorriente.chass.ncsu. edu/index.php/acontracorriente/article/view/1566/2830

- DELEUZE, G. y GUATTARI, F. (1995). ¿Qué es la filosofía? Barcelona: Anagrama.

• EGIDO, A. (1985). Prólogo". En Alciato, Emblemas (pp. 7-17). Madrid: Akal.

- FOUCAULT, M. (1992). Nietzsche, la Genealogía, la Historia. Microfísica del poder (pp. 7-29). Madrid: De la piqueta.

- GARCÍA, R. (2002). De un mar a otro. Prólogo a Aldo Oliva, Una batalla. Poemas inéditos. Poemas últimos (1978/2000) (pp. 7-19). Rosario: Aldebarán. 
- _ (2016). La ética del futuro. en Oliva, A. Poesía completa (pp. 7-53). Rosario: Editorial Municipal de Rosario.

- GINZBURG, C. (1999). De A. Warburg a E. H. Gombrich. Notas sobre un problema de método. En Mitos, emblemas, indicios (pp. 38-93). Barcelona: Gedisa.

- NIETZSCHE, F. (2002). De la utilidad y los inconvenientes de la Historia para la vida. En Consideraciones intempestivas (pp. 18-96). Buenos Aires: Alianza.

- OLIVA, A. (2000 [1996]). Charla del poeta Aldo Oliva (marzo de 1996). Endymion, 2, 10-17.

- - (2016). Poesía completa. Rosario: Editorial Municipal de Rosario.

- _- (2016 [1988]). Me siento un hijo ilegítimo de esta cultura. Entrevista realizada por Martín Prieto y Daniel García Helder, publicada originalmente en Diario de poesía, (9). En Oliva, A. Entrevistas 1988-1999 (pp. 1-6). Rosario: Editorial Municipal de Rosario.

-__ (2016 [1993]). Cuando hablo, hablo de poesía; cuando escribo, escribo poesía. Entrevista realizada por Susana Rosano, publicada originalmente en La Capital, 31 de diciembre. En Oliva, A. Entrevistas 1988-1999 (pp. 7-10). Rosario: Editorial Municipal de Rosario.

- _ (2016 [1994]). Un poema es un continuo levantamiento de sentidos. Entrevista realizada por Osvaldo Aguirre, publicada originalmente en Vasto Mundo, (7). En Oliva, A. Entrevistas 1988-1999 (pp. 15-22). Rosario: Editorial Municipal de Rosario. - PAZ, O. (2005). Los hijos del limo. Del romanticismo a la vanguardia. México: Ligeia. 